\title{
TSTA3 wt Allele
}

National Cancer Institute

\section{Source}

National Cancer Institute. TSTA3 wt Allele. NCI Thesaurus. Code C156968.

Human TSTA3 wild-type allele is located in the vicinity of $8 \mathrm{q} 24.3$ and is approximately $5 \mathrm{~kb}$ in length. This allele, which encodes GDP-L-fucose synthase protein, plays a role in GDPL-fucose synthesis. 